\title{
PENGEMBANGAN MODEL PEMBELAJARAN PEMECAHAN MASALAH BERORIENTASI KEARIFAN LOKAL PADA SISWA SMP DI KOTA SINGARAJA
}

\author{
N.N. Parwati \\ Fakultas MIPA \\ Universitas Pendidikan Ganesha \\ Singaraja, Indonesia \\ E-mail: parwatimat@gmail.com
}

\begin{abstract}
Abstrak
Tujuan penelitian pengembangan ini adalah menghasilkan (1) prototipe model pembelajaran pemecahan masalah berorientasi kearifan lokal; (2) buku pegangan siswa; (3) lembar kerja siswa (LKS); (4) RPP; dan (5) buku petunjuk guru. Penelitian ini direncanakan berlangsung selama tiga tahun, dengan mengadaptasi model 4 D (Define, Design, Develop, and Disseminate). Pada tahun ini, pelaksanaan tahap define dan design untuk melakukan analisis kebutuhan dan penyusunan prototipe model dan perangkat pembelajaran. Hal ini dilakukan dengan (a) studi lapangan dan studi pustaka, (b) kerja tim untuk merancang prototipe model dan perangkat pembelajarannya, (c) validasi ahli dan panel group discussion untuk melakukan pengkajian kesesuaian prototipe tadi dengan karakteristik siswa. Analisis data dilakukan secara deskriptif. Hasil penelitian menunjukkan prototipe model dan perangkat pembelajaran yang dikembangkan berkualifikasi 'valid'.
\end{abstract}

Kata kunci: kearifan lokal, model pembelajaran pemecahan masalah.

\begin{abstract}
The purposes of this research and development are to produce (1) a prototype of problemsolving learning model oriented local wisdom, (2) student handbook, (3) student worksheet (LKS), (4) lesson plans, and (5) teacher guide. This study is planned to last for three years, with adapted the $4 \mathrm{D}$ models (Define, Design, Develop, and Disseminate). In this year, the implementation of define and design stage to conduct needs assessment and preparation prototype of model and learning tools. This is done by (a) field studies and literature, (b) team work to design prototype of model and learning tools, (c) experts validation and panel group discussion for assessing the suitability of the prototype was to student characteristics. The data were analyzed descriptively. The results show that the prototype of model and learning tools developed are 'valid' qualification.
\end{abstract}

Keywords: local wisdom, problem-solving learning model.

\section{PENDAHULUAN}

Beberapa dampak negatif yang ditimbulkan dari kemajuan teknologi dan informasi adalah pola hidup komsumtif, kekerasan, kejahatan seksual, tawuran antar pelajar, dan kehidupan politik yang tidak mendidik (Mendiknas, 2010). Lembaga-lembaga pendidikan memiliki peran utama dalam upaya mencegah dampak negatif yang ditimbulkan dari perkembangan tersebut. Beberapa hal yang bisa dilakukan dalam menanggulangi masalah tersebut, adalah: menyelenggarakan pedidikan dengan menekankan pada pengembangan pendidikan karakter sesuai dengan tujuan pendidikan nasional (UU Sisdiknas no. 20 tahun 2003). Seseorang akan memiliki karakter yang baik apabila ia memiliki kemampuan untuk memecahkan permasalahan yang dihadapi secara bertanggung jawab. Di samping itu, ia harus mampu berprilaku sesuai dengan norma-norma yang berlaku dalam masyarakat.

Salah satu mata pelajaran yang diberikan di sekolah mulai dari sekolah dasar (SD) dalam upaya mencapai tujuan pendidikan nasional tersebut adalah mata pelajaran matematika. Tujuan pendidikan matematika sekolah 
ada beberapa, diantaranya: memahami konsep matematika, menjelaskan keterkaitan antar konsep dan mengaplikasikan konsep atau algoritma secara luwes, akurat, efisien, dan tepat dalam pemecahan masalah; menggunakan penalaran divergen maupun konvergen, melakukan manipulasi matematika dalam membuat generalisasi, menyusun bukti, atau menjelaskan gagasan dan pernyataan matematika; memecahkan masalah yang meliputi kemampuan memahami masalah, merancang model matematika, menyelesaikan model dan memperoleh solusi yang benar; mengkomunikasikan gagasan dengan simbol, tabel, diagram, atau media lain untuk memperjelas keadaan atau masalah; menghargai kegunaan matematika dalam kehidupan, yaitu memiliki rasa ingin tahu, perhatian, dan minat dalam mempelajari matematika, serta ulet dan percaya diri dalam pemecahan masalah. (Depdiknas, 2006; NCTM, 2000).

Sampai saat ini pelaksanaan pembelajaran matematika belum mampu mencapai tujuan pendidikan yang ditetapkan tersebut secara optimal. Hampir setiap tahun pada saat diadakan ujian nasional, berita tentang rendahnya prestasi belajar matematika tersiar di media massa. Di samping itu hasil-hasil penelitian yang mengungkap tentang rendahnya hasil belajar matematika, telah banyak dilakukan (Miguel, 2006; Parwati, dkk., 2008).

Menyimak fokus dan tujuan pendidikan matematika tersebut, selain rendahnya hasil belajar matematika siswa, tampaknya masih banyak masalah yang dihadapi dalam upaya pencapaiannya. Beberapa permasalahan tersebut adalah kreativitas berpikir siswa tidak berkembang dan pelaksanaan pembelajaran belum difokuskan dalam pencapaian kemampuan pemecahan masalah (Mendiknas, 2010; Klavir \& Hershkovitz, 2008; Miguel, 2006; Nohda, 2000). Apabila dicermati akar permasalahan tersebut ada beberapa, diantaranya: (1) model pembelajaran matematika yang digunakan sampai saat ini belum adaptif dengan perkembangan jaman, yaitu masih 'teacher centered'; (2) pelaksanaan pembelajaran masih didominasi oleh kegiatan pencapaian basic skills saja, belum difokuskan pada kegiatan pemecahan masalah; (3) bahan ajar yang digunakan, belum dirancang berorientasi pada nilai-nilai kearifan lokal sehingga kurang mengarah pada pengembangan pendidikan karakter.

Kemampuan

memecahkan

masalah adalah kemampuan kognitif tingkat tinggi. Sukmadinata dan As'ari (2005 : 24) menambahkan tahap berpikir pemecahan masalah setelah tahap evaluasi yang menjadi bagian dari tahapan kognitif Bloom. Hal ini menunjukkan bahwa kemampuan memecahkan masalah adalah kemampuan kognitif tingkat tinggi.

Menurut Suherman (2003: 7) Model pembelajaran dimaksudkan sebagai pola interaksi siswa dengan guru di dalam kelas yang menyangkut strategi, pendekatan, metode, dan teknik pembelajaran yang diterapkan dalam pelaksanaan kegiatan belajar mengajar di kelas. Konsep yang dikemukakan Suherman menjelaskan bahwa model pembelajaran adalah suatu bentuk bagaimana interaksi yang tercipta antara guru dan siswa berhubungan dengan strategi, pendekatan, metode, dan teknik pembelajaran yang digunkan dalam proses pembelajaran.

Gijselaers (1996) Pembelajaran berbasis masalah diturunkan dari teori bahwa belajar adalah proses dimana pembelajar secara aktif mengkontruksi pengetahuan. Muslimin Ibrahim (2000:7) Pembelajaran berdasarkan masalah tidak dirancang untuk membantu guru memberikan informasi sebanyak banyaknya kepada siswa, akan tetapi pembelajaran berbasis masalah dikembangkan untuk membantu siswa mengembangkan kemampuan berfikir, pemecahan masalah, dan ketrampilan intelektual, belajar berbagai peran orang dewasa melalui pelibatan mereka dalam pengalaman nyata atau simulasi dan menjadi pembelajar yang mandiri. 
Pannen (2001) Langkah-langkah pemecahan masalah dalam pembelajaran $\mathrm{PBL}$ paling sedikit ada delapan tahapan, yaitu: 1. mengidentifikasi masalah, 2. mengumpulkan data, 3. menganalisis data, 4. memecahkan masalah berdasarkan pada data yang ada dan analisisnya, 5. memilih cara untuk memecahkan masalah, 6. merencanakan penerapan pemecahan masalah, 7. melakukan ujicoba terhadap rencana yang ditetapkan, dan 8 . melakukan tindakan (action) untuk memecahkan masalah,

$$
\text { Pemecahan masalah adalah }
$$

suatu kemampuan berpikir yang menuntut suatu tahapan berpikir. Polya (Schoenfeld, 1980) dalam bukunya How to Solve It pertama kali mengenalkan 4 langkah dalam pemecahan masalah yang disebut Heuristik. Strategi berpikir pemecahan masalah menurut Polya dijadikan sebagai model umum strategi pemecahan masalah. Sementara pengembangannya memuat langkah yang lebih rinci dan spesifik.

Berdasarkan permasalahan yang telah diuraikan tersebut, tampaknya sangat urgen dilakukan perubahan paradigma pembelajaran matematika di SMP, dari pembelajaran yang teacher centered ke student centered. Selain itu, pelaksanaan pembelajaran matematika agar tidak terlepas dari konteks kehidupan siswa dan tidak mengabaikan unsur-unsur kearifan lokal (Klavir \& Hershkovitz, 2008). Dalam hal ini, yang perlu dilakukan adalah lebih banyak mengaitkan materi matematika dengan manfaatnya dalam kehidupan sehari-hari atau memilih konteks menggunakan unsur-unsur kearifan lokal yang kaya dengan pendidikan karakter bangsa. Sejak dini siswa diajak belajar matematika mulai dari lingkungan/ budaya disekitar mereka.

Melalui matematika siswa dilatih untuk mengembangkan fungsi otak kiri dan fungsi otak kanan sebagaimana telah diuraikan dalam kajian sebelumnya. Agar semua fungsi tersebut berjalan secara efektif maka diperlukan pemilihan model pembelajaran yang tepat dalam implementasi pembelajarannya. Salah satu model pembelajaran yang akomodatif untuk pencapaian kemampuan pemecahan masalah matematika adalah model pembelajaran pemecahan masalah (Krulik \& Rudnick, 1996). Pelaksanaan model pembelajaran ini akan lebih efektif dalam mencapai tujuan pendidikan sebagaimana yang tertuang dalam UU Sisdiknas no. 20 tahun 2003 dan tujuan pendidikan matematika khususnya, perlu dikembangkan dengan pengintegrasian nilai-nilai kearifan lokal.

Kearifan lokal adalah cara-cara dan praktik-praktik yang dikembangkan oleh sekelompok masyarakat, yang berasal dari pemahaman mendalam mereka akan lingkungan setempat, yang terbentuk dari tinggal di tempat tersebut secara turun temurun (Rajib, 2008). Apabila dicermati pengertian tersebut, dapat dikelompokkan menjadi dua jenis kearifan lokal, yaitu kearifan lokal sosial (local wisdom), misalnya slogan-slogan yang memiliki nilai-nilai tertentu dan kearifan lokal ekologi (lokal genius), misalnya menyelimuti pohon dengan kain memiliki makna agar tidak ditebang dengan sembarangan. Dalam penelitian ini nilai-nilai kearifan lokal yang digunakan adalah kearifan lokal sosial.

Model pembelajaran pemecahan masalah didasari oleh teori belajar kognitif dan konstruktivisme yang mengasumsikan bahwa anak memiliki rasa ingin tahu bawaan dan secara terus menerus berusaha memahami dunia di sekitarnya dan menganggap bahwa kelas merupakan cermin masyarakat yang lebih besar dan berfungsi sebagai laboratorium untuk belajar memecahkan masalah kehidupan nyata (Rizvi, 2004; Parwati, 2011). Asumsi lain adalah, perkembangan intelektual akan terjadi pada saat individu berhadapan dengan pengalaman baru dan menantang serta ketika mereka berusaha untuk memecahkan masalah yang dimunculkan oleh pengalaman ini (Krulik \& Rudnick, 1996; Muslimin, 2000). Pelaksanaan model pembelajaran pemecahan masalah dalam pembelajaran matematika memberikan 
peluang yang sangat besar untuk pengembangan pendidikan karakter. Hal ini dilakukan melalui pengintegrasian nilai-nilai kearifan lokal dalam setiap langkah-langkah/fase-fase kegiatannya.

Secara umum tujuan penelitian ini adalah menghasilkan model pembelajaran pemecahan masalah dengan pengintegrasian nilai-nilai kearifan lokal beserta perangkat pembelajaran matematika yang efektif dalam pencapaian kemampuan pemecahan masalah matematika pada siswa SMP. Tujuan-tujuan khusus penelitian ini adalah sebagai berikut. (1) Melalui studi lapangan dan studi pustaka, melakukan analisis kebutuhan terkait dengan karakteristik bahan ajar, karakteristik siswa, analisis pendidikan karakter yang mungkin dikembangkan, dan analisis konteks yang relevan dengan materi matematika SMP. (2) Melalui team work, merancang prototipe model pembelajaran dan prototipe perangkat pembelajaran sesuai dengan pokok-pokok bahasan matematika SMP.

(3) Melalui panel group discussion, menghasilkan bahan kajian kesesuaian model pembelajaran dan prototipe perangkat pembelajaran dengan karakteristik siswa serta peluangnya untuk Mengembangkan kemampuan pemecahan masalah. (4) Melalui validasi pakar dan panel group discussion, mendapatkan kajian tentang kebenaran konsep, dan keterbacaan paket pembelajaran. (5) Melalui team work, menghasilkan model dan prototipe perangkat pembelajaran yang telah disempurnakan berdasarkan hasil validasi pakar, serta medianya yang siap diuji coba terbatas untuk diperbaiki lagi, dan diuji kelayakannya secara empiris.

Manfaat penelitian ini adalah untuk mengoptimalkan pencapaian tujuan pendidikan nasional. Salah satu tujuan pendidikan nasional, khususnya tujuan pendidikan matematika adalah membekali peserta didik dengan kemampuan pemecahan masalah. Sebagaimana disebutkan dalam pembahasan sebelumnya, yaitu kebutuhan hidup di era globalisasi semakin kompleks, sehingga tidak menutup kemungkinan permasalahanpermasalahan yang akan dihadapi oleh umat manusia semakin kompleks, bahkan kadang-kadang tidak menentu. Dalam menghadapi situasi demikian, dunia pendidikan diharapkan mampu menyesuaikan kurikulum sehingga adaptif dengan perkembangan zaman. Di samping itu, melalui belajar matematika, terbuka peluang yang sangat besar untuk membentuk karakter bangsa yang lebih baik.

Sampai saat ini pemecahan masalah belum dijadikan fokus dalam melaksanakan pembelajaran matematika khususnya di sekolah menengah. Sebagai dampaknya, kemampuan pemecahan masalah dan hasil belajar matematika siswa sangat rendah (Parwati, 2011). Di samping itu model pembelajaran dan perangkat pembelajaran yang digunakan dalam pembelajaran sampai saat ini belum difokuskan pada pengembangan pendidikan karakter (Puskur, 2010).

Perangkat pembelajaran yang dikembangkan dalam penelitian ini sangat urgen untuk mengatasi masalah minimnya perangkat pembelajaran matematika yang valid dan teruji, yang berorientasi pada pengembangan kemampuan pemecahan masalah, terutama ketiadaan buku-buku dan LKS yang memuat masalah matematika tertutup maupun masalah matematika terbuka.

Bagi calon guru, guru dan dosen, pelaksanaan model pembelajaran dan pengembangan perangkat pembelajaran yang dilakukan dalam penelitian ini diharapkan dapat dijadikan pedoman dalam melakukan inovasi model pembelajaran matematika beserta perangkatnya, yang menekankan pada nilai-nilai kearifan lokal yang efektif dalam pencapaian kemampuan pemecahan masalah matematika siswa.

\section{METODE}

Penelitian ini merupakan penelitian pengembangan selama tiga tahun, dengan mengadaptasi pola $4 \mathrm{D}$ (Define, Design, Develop, and Disseminate) (Thiagarajan, dkk., 1974). Kegiatan penelitian yang telah 
dilakukan yang berkaitan dengan penelitian pengembangan ini adalah melakukan penelitian yang mengkaji tentang pembelajaran matematika yang memfokuskan kajian pada pemecahan masalah matematika open-ended (terbuka). Penelitian tersebut telah dilakukan pada jenjang sekolah dasar sampai perguruan tinggi. Kegiatan penelitian yang telah dilakukan, meliputi: (1) pelaksanaan pendekatan open-ended yang mengacu pada model belajar mandiri dalam rangka meningkatkan kualitas prestasi belajar mahasiswa, tahun 2004; (2) implementasi model pembelajaran berdasarkan masalah dalam rangka mengefektifkan pelaksanaan kurikulum berbasis kompetensi pada siswa SMP, tahun 2005; (3) implementasi model pembelajaran reasoning and problem solving berbasis open-ended problem untuk meningkatkan kompetensi penalaran dan komunikasi matematik pada siswa SMP, tahun 2006; dan (4) pengembangan perangkat pembelajaran matematika berpendekatan tematik berorientasi masalah matematika terbuka untuk mengembangkan kemampuan berpikir kritis dan kreatif pada siswa SD, tahun 2007 \& 2008).

Penelitian yang dilakukan sebelumnya, memfokuskan kajian pada jenis-jenis masalah matematika, baik masalah matematika terbuka (openended) maupun masalah matematika tertutup (close-ended) dengan model dan pendekatan pembelajaran yang relevan dengan pemecahan masalah. Namun, penelitian sebelumnya belum memfokuskan kajian pada pengintegrasian nilai-nilai kearifan lokal. Sebagaimana yang diamanatkan dalam UU Sisdiknas, dalam pelaksanaan penelitian ini, model dan perangkat pembelajaran matematika dikembangkan dengan memfokuskan kajian pada pengintegrasian nilai-nilai kearifan lokal pada siswa SMP khususnya (UU Sisdiknas no. 20 tahun 2003).

Kegiatan penelitian pada tahun ini adalah pendesainan prototipe model pembelajaran beserta perangkatnya dan validasi ahli. Perancangan prototipe pembelajaran matematika dan perangkatnya berorientasi pada nilainilai kearifan lokal. Hasil yang ditargetkan, yaitu (a) draf I prototipe model dan perangkat pembelajaran dan (b) instrumen penelitian berupa tes kemampuan pemecahan masalah yang siap untuk diuji coba secara terbatas pada tahun II, terkait dengan uji keterbacaan dan kelayakan. Kegiatan men-design prototipe ini, difokuskan untuk menghasilkan (i) konteks-konteks yang relevan, (ii) nilai-nilai kearifan lokal yang mungkin dikembangkan, (iii) rentangan bahan ajar matematika (content strands), (iv) dimensi kompetensi matematis siswa (mathematical abilities and power) dan (v) rentangan hasil belajar matematika (learning outcomes) yang sesuai dengan tuntutan kurikulum 2013 dan cocok untuk dikembangkan dan digunakan pada sekolah menengah pertama.

\section{HASIL DAN PEMBAHASAN}

Pada tahap analisis kebutuhan dilakukan pengkajian terhadap unsurunsur kearifan lokal masyarakat Bali yang layak diintegrasikan dalam merancang model pembelajaran dan buku siswa. Hasil kajian seperti pada tabel 1.

Tabel 1. Nilai-nilai Kearifan Lokal Bali yang Layak Diintegrasikan dalam Pembelajaran

\begin{tabular}{|c|c|c|}
\hline No. & Kearifan Lokal Bali & Makna yang Terkandung \\
\hline 1. & $\begin{array}{l}\text { Joh pejalane liu ane } \\
\text { tepukin. }\end{array}$ & $\begin{array}{l}\text { Orang yang suka berpergian jauh, akan banyak } \\
\text { mengenal tempat-tempat baru. }\end{array}$ \\
\hline 2. & $\begin{array}{l}\text { Puntul-puntulan tiuke, yen } \\
\text { sai sangihin pedas dadi } \\
\text { mangan. }\end{array}$ & $\begin{array}{l}\text { Setumpul-tumpulnya pisau jika terus diasah nantinya } \\
\text { akan tajam juga. }\end{array}$ \\
\hline 3. & $\begin{array}{l}\text { Saririh-ririh semale } \\
\text { makecog, diacepoke bisa } \\
\text { ulung. }\end{array}$ & $\begin{array}{l}\text { Sepandai-pandainya tupai melompat, suatu ketika } \\
\text { bisa jatuh juga. }\end{array}$ \\
\hline
\end{tabular}




\begin{tabular}{|c|c|c|}
\hline No. & Kearifan Lokal Bali & Makna yang Terkandung \\
\hline 4. & $\begin{array}{l}\text { Yeh ngetel di capcapane } \\
\text { bisa ngesongin batu. }\end{array}$ & $\begin{array}{l}\text { Tetesan air yang terus menerus bisa juga mengikis } \\
\text { batu. }\end{array}$ \\
\hline 5. & Taru tan luputing angin. & Pohon taru tidak pernah luput dari terpaan angin. \\
\hline 6. & De cara kayu pule. & $\begin{array}{l}\text { Jangan seperti pohon pule. Pohon pule dikenal } \\
\text { sebagai pohon besar yang dapat dimanfaatkan } \\
\text { sebagai perindang maupun obat-obatan, tetapi tidak } \\
\text { dapat menghasilkan apa-apa untuk dirinya sendiri } \\
\text { (tidak berbuah, tidak berumbi). }\end{array}$ \\
\hline 7. & Hidupe care punyan biu. & $\begin{array}{l}\text { Hidup ini seperti pohon pisang. Pohon pisang hidup } \\
\text { dalam satu siklus pendek, yaitu tumbuh berupa } \\
\text { tunas, berkembang menjadi tumbuhan dewasa, } \\
\text { berbuah, dan mati. }\end{array}$ \\
\hline 8. & Hidupe care ambengan. & $\begin{array}{l}\text { Hidup ini seperti tumbuhan ilalang. Tumbuhan ilalang } \\
\text { ketika muda sangatlah tajam, tetapi ketika sudah tua } \\
\text { tidak tajam lagi. }\end{array}$ \\
\hline 9. & $\begin{array}{l}\text { De ngaden awak bise, } \\
\text { depang anake ngadanin. }\end{array}$ & $\begin{array}{l}\text { Jangan menilai diri sendiri bisa, biar orang lain yang } \\
\text { menilai. }\end{array}$ \\
\hline 10. & $\begin{array}{l}\text { De anyar-anyaran gerang } \\
\text { bangkuk. }\end{array}$ & $\begin{array}{l}\text { Jangan seperti orang yang membangun sesuatu } \\
\text { diawalnya saja bersemangat. Belum mencapai akhir, } \\
\text { ia sudah menyerah. }\end{array}$ \\
\hline 11. & $\begin{array}{l}\text { Caruk gong, muah aud } \\
\text { kelor. }\end{array}$ & $\begin{array}{l}\text { Seperti orang yang bekerja bakti di masyarakat, } \\
\text { semuanya harus ikut serta. }\end{array}$ \\
\hline 12. & De ketangkeb langit. & Jangan terlalu takut kepada orang lain. \\
\hline 13. & Paksi bina paksa. & Lain orang, lain pula pemikirannya. \\
\hline 14. & $\begin{array}{l}\text { De liunan krebek kuangan } \\
\text { ujan. }\end{array}$ & $\begin{array}{l}\text { Jangan banyak bicara, tetapi tidak memiliki } \\
\text { kemampuan. }\end{array}$ \\
\hline 15. & Gede kayu, gede papanne. & $\begin{array}{l}\text { Besar usaha yang dilakukan, besar pula hasil yang } \\
\text { diperoleh. }\end{array}$ \\
\hline 16. & $\begin{array}{l}\text { De megae buka anake } \\
\text { anyang-anyangan. }\end{array}$ & Jangan bekerja dengan tidak bersungguh-sungguh. \\
\hline 17. & $\begin{array}{l}\text { De gancangan tindak } \\
\text { kuangan daya. }\end{array}$ & $\begin{array}{l}\text { Jangan hanya cepat dalam bertindak, tetapi tidak } \\
\text { memikirkan apa yang dilakukan. }\end{array}$ \\
\hline 18. & $\begin{array}{l}\text { Pales rajah aji golok } \\
\text { Males mlajah dadi belog. }\end{array}$ & Malas belajar akan membuat orang menjadi bodoh. \\
\hline
\end{tabular}

Pengintegrasian nilai-nilai kearifan lokal tersebut sebagai sumber motivasi siswa untuk belajar dan untuk menjembatani pembentukan karakter yang positif pada siswa. Pada buku siswa dan LKS, nilai-nilai kearifan lokal tersebut dimunculkan sesuai dengan motivasi yang ingin disampaikan dan ketepatan penggunaannya dengan langkah-langkah pembelajaran. Sebagai contoh, pada bagian awal buku siswa (sebelum masuk pada paparan materi) dimunculkan slogan "puntul-puntulan tiyuke yen sai sangihin pedas dadi mangan" dilengkapi dengan artinya dalam bahasa Indonesia dan motivasi yang ingin disampaikan. Slogan tersebut berarti setumpul-tumpulnya pisau kalau sering diasah pasti akan tajam juga. Makna yang ingin disampaikan adalah "sebodoh-bodohnya" manusia kalau rajin belajar pasti akan menjadi pintar. Karakter yang ingin dibangun adalah agar siswa memiliki motivasi untuk terus belajar dan tertanam dalam dirinya suatu keyakinan bahwa kalau mereka tekun dalam mempelajari sesuatu, maka mereka pasti bisa.

Pengintegrasian nilai kearifan lokal dalam model pembelajaran pemecahan masalah yang dikembangkan dalam penelitian ini, memiliki beberapa fase versi Krulik \& Rudnick (1996) dengan prinsip-prinsip reaksi seperti pada Tabel 2 . 
Tabel 2. Fase-fase Model Pembelajaran Pemecahan Masalah berorientasi Kearifan Lokal Masyarakat Bali

\begin{tabular}{llll}
\hline \multicolumn{1}{c}{ Fase } & \multicolumn{1}{c}{ Prinsip Reaksi } & \multicolumn{1}{c}{ Karakter yang } \\
Dibangun
\end{tabular}

Lingkungan belajar dalam hal ini mempunyai ciri: terbuka, proses demokratis dan peranan siswa aktif. Keseluruhan proses pembelajaran membantu siswa menjadi mandiri, siswa otonom yang percaya pada keterampilan intelektual mereka sendiri, lingkungan berorientasi inkuiri. Walaupun tahapan-tahapan tesebut terstruktur, namun norma di sekitar pembelajaran adalah terbuka dan bebas mengemukakan pendapat. Lingkungan belajar menekankan pada peranan sentral siswa, bukan guru. Dampak instruksional dan pengiring dari model pembelajaran pemecahan masalah (PM) adalah seperti Gambar 1. 


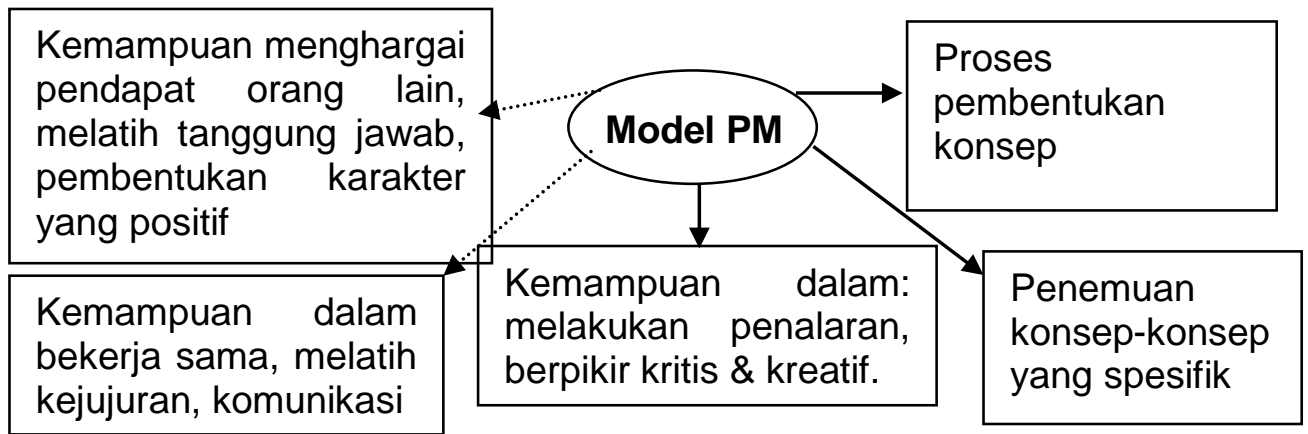

Keterangan: — dampak instruksional dampak pengiring

Gambar 1. Dampak Instruksional dan Dampak Pengiring Model Pembelajaran

Pemecahan Masalah

Validasi perangkat pembelajaran yang dikembangkan dilakukan oleh 2 orang validator, yaitu satu orang ahli pendidikan matematika dan satu orang guru matematika SMP yang telah berpengalaman mengajar lebih dari 5 tahun. Hasil validasi dipaparkan sebagai berikut.

Tabel 3. Hasil Validasi RPP

\begin{tabular}{|c|c|c|}
\hline \multirow{2}{*}{ Aspek yang dinilai } & \multicolumn{2}{|c|}{ Jumlah skor validator } \\
\hline & I & II \\
\hline $\begin{array}{l}\text { 1. Kompetensi, indikator, perangkat dan media (5 } \\
\text { deskriptor) }\end{array}$ & 19 & 19 \\
\hline 2. Langkah-langkah pembelajaran (4 deskriptor) & 16 & 15 \\
\hline 3. Evaluasi dan asesmen pembelajaran (2 deskriptor) & 8 & 8 \\
\hline 4. Manfaat RPP (3 deskriptor) & 12 & 11 \\
\hline Total skor & 55 & 53 \\
\hline Rata-rata skor (total skor : 14) & 3,93 & 3,79 \\
\hline Kualifikasi & Baik sekali & Baik sekali \\
\hline Rata-rata keseluruhan $(3,93+3.79) / 2$ & 3,86 (baik s & (ali) \\
\hline
\end{tabular}

Hasil validasi perangkat pembelajaran, yaitu: Rencana Pelaksanaan Pembelajaran (RPP), buku pegangan siswa beserta lembar kerja siswa (LKS), dan buku petunjuk guru masing-masing dilaporkan seperti berikut.

a. Hasil validasi RPP

Validasi RPP dilakukan oleh 2 orang validator (1 orang ahli pendidikan matematika sekolah dasar dan 1 orang guru senior matematika SD). Validasi RPP dilakukan meliputi 5 aspek dengan rentangan skor masing-masing aspek adalah 1 sampai 4. Analisis ini didasarkan pada skor rata-rata $(\bar{X})$, mean ideal (MI) dan standar deviasi ideal (SDI). Hasil validasi disajikan dalam Tabel
3.

b. Hasil validasi buku siswa dan buku petunjuk guru.

Validasi buku siswa dilakukan oleh validator yang sama dengan validator RPP dan dianalisis dengan cara yang sama pula. Validasi buku siswa dilakukan meliputi 6 aspek dengan rentangan skor untuk masing-masing deskriptor adalah 1 sampai 4 . Hasil validasi disajikan dalam Tabel 4.

c. Validasi buku petunjuk guru, menggunakan 6 aspek yang sama dengan buku siswa dengan rentangan skor untuk masing-masing deskriptor adalah 1 sampai 4. Ratarata skor validator diperoleh sebesar 3, 76 berada dalam kategori 'baik 
sekali'. Criteria valid adalah minimal berada dalam kategori 'baik'.

d. Validasi tes kemampuan pemecahan masalah matematika dan rubrik penskoran, meliputi 3 aspek penilaian, dan 11 deskriptor. Aspek
Materi terdiri dari 4 deskriptor, aspek konstruksi terdiri dari 4 deskriptor, dan aspek penggunaan bahasa terdiri dari 3 deskriptor. Rata-rata skor validator diperoleh sebesar 3,65 berada dalam kategori 'valid'.

Tabel 4. Hasil Validasi Buku Siswa

\begin{tabular}{|c|c|c|c|}
\hline \multirow{2}{*}{\multicolumn{2}{|c|}{ Aspek yang dinilai }} & \multicolumn{2}{|c|}{ Jumlah skor validator } \\
\hline & & I & II \\
\hline 1. & $\begin{array}{l}\text { Perumusan judul dan indikator hasil belajar } \\
\text { (4 deskriptor) }\end{array}$ & 16 & 16 \\
\hline 2. & $\begin{array}{l}\text { Masalah matematika yang akan dipecahkan } \\
\text { (4 deskriptor) }\end{array}$ & 16 & 15 \\
\hline 3. & Paparan materi (4 deskriptor) & 15 & 15 \\
\hline 4. & $\begin{array}{l}\text { Evaluasi dan asesmen pembelajaran } \\
\text { ( } 2 \text { deskriptor) }\end{array}$ & 8 & 8 \\
\hline 5. & $\begin{array}{l}\text { Bentuk fisik dan penggunaan bahasa } \\
\text { (4 deskriptor) }\end{array}$ & 16 & 12 \\
\hline 6. & $\begin{array}{c}\text { Manfaat bahan ajar (2 deskriptor) } \\
\text { Total skor }\end{array}$ & $\begin{array}{c}8 \\
79\end{array}$ & $\begin{array}{c}7 \\
73\end{array}$ \\
\hline & Rata-rata skor (total skor : 20) & 3.95 & 3.65 \\
\hline & Kualifikasi & Baik sekali & Baik sekali \\
\hline & Rata-rata keseluruhan $(3,95+3,65) / 2$ & $3.80 \quad(k$ & aik sekali) \\
\hline
\end{tabular}

Kriteria kevalidan, keefektifan, dan kelayakan dari model dan perangkat pembelajaran yang dikembangkan dalam penelitian ini, berupa ketercapaian tujuan proses dan hasil.

Draf perangkat pembelajaran yang telah dihasilkan, salah satunya adalah buku matematika siswa SMP berorientasi kearifan lokal Bali. Dalam penyusunannya disesuaikan dengan langkah-langkah model pembelajaran pemecahan masalah. Pada bagian awal, disajikan permasalahan sehari-hari siswa. Hal ini dimaksudkan agar siswa bisa mengaitkan langsung materi matematika yang dipelajari dengan kegunaannya dalam kehidupan mereka. Hal ini didukung oleh pendapat yang mengatakan bahwa penyajian masalah sehari-hari akan membuat pelajaran menjadi lebih bermakna (Gravemeijer, K., \& Doorman, M., 1999; Handal \& Bobis, 2003).

Ada beberapa hal penting yang perlu dicermati dalam pelaksanaan strategi pembelajaran pemecahan masalah berorientasi kearifan lokal Bali agar dapat dilaksanakan secara efektif, khususnya dalam pembelajaran Matematika SMP, yaitu: (1) pada awal pembelajaran, siswa agar diberikan masalah sebagai motivator bagi mereka untuk mempelajari materi selanjutnya dan biarkan mereka untuk mencari jawaban sendiri sesuai dengan pengetahuan yang telah dimiliki; (2) berikan siswa motivasi belajar dengan mengingatkan/membaca dan merenungkan slogan-slogan/petuahpetuah yang diangkat dari kearifan lokal yang mengandung pesan-pesan moral untuk memperkuat karakter positif siswa; (2) ciptakan situasi yang menyenangkan bagi siswa, misalnya mengajak mereka bernyanyi dengan membuat syair lagu yang dikaitkan dengan materi yang sedang dibahas atau mengemas pembelajaran dalam bentuk permainan; (3) masalah yang disajikan untuk siswa adalah masalah yang kontekstual/sesuai dengan lingkungan sehari-hari siswa, sehingga materi matematika yang sedang dipelajari dapat dilihat langsung manfaatnya atau dapat dibayangkan dalam pikiran siswa; (4) pelaksanaan 
pembelajaran yang bertipe problem solving, agar diberikan berupa masalah matematika terbuka maupun masalah matematika tertutup; (5) lakukan kegiatan pembelajaran dalam bentuk kerja kelompok, dengan membentuk kelompok yang heterogen; dan (6) guru mengambil peran sebagai fasilitator dan mediator yang kreatif.

Berdasarkan hasil validasi ahli dan pengguna diperoleh bahwa model dan perangkat pembelajaran yang dihasilkan telah memenuhi kriteria valid. Perangkat pembelajaran yang telah dihasilkan, agar memenuhi kriteria efektif dan layak pakai masih memerlukan uji lanjutan berupa uji coba secara empirik. Uji coba empirik, akan dilakukan pada penelitian tahap berikutnya.

\section{SIMPULAN DAN SARAN}

$\begin{array}{rlr}\text { Draf model pembelajaran } & \text { perorientas } \\ \text { pemecahan masalah }\end{array}$ kearifan lokal Bali yang dihasilkan dalam penelitian ini berkualifikasi 'valid'. Perangkat pembelajaran, meliputi buku petunjuk guru, RPP, dan buku siswa yang dihasilkan dalam penelitian ini berkualifikasi "sangat baik", dengan demikian telah memenuhi kriteria 'valid'. Tes kemampuan pemecahan masalah matematika dan rubrik penskoran, berada dalam kategori 'valid'. Dengan demikian, dapat disimpulkan Model dan perangkat pembelajaran yang dihasilkan dalam penelitian pengembangan ini, semua berkualifikasi valid. Namun, model dan perangkat pembelajaran yang dihasilkan tersebut masih perlu diuji secara empirik untuk dapat digunakan dalam skala yang lebih besar.

\section{DAFTAR PUSTAKA}

Building a nation of Character. 2008. Pendidikan Holistik Berbasis Karakter. Jakarta.

Depdiknas. 2006. Permendiknas Nomor 22 Tahun 2006 tentang Standar Isi untuk Satuan Pendidikan Dasar dan Menengah. Jakarta.

Gravemeijer, K., \& Doorman, M. 1999. Context Problem in Realistic Mathematics Education: A Calculus Course as an Example. Educational Studies in
Mathematics, 39: 111-129.

Heuvel-Panhuizen, V. D. 2000. Mathematics Education in the Netherlands a Guided Tour. (Online) ( http://www.fi.uu.nl/en/ indexpublicaties.hrml). Diakses 2 April 2013.

Klavir, R. \& Hershkovitz, S. 2008. Teaching and Evaluating 'OpenEnded' Problems. International Journal for Mathematics Teaching and Learning: 5 (20): 325.

Krulik, S., \& Rudnick, J. A. 1996. The New Sourcebook for Teaching Reasoning and Problem Solving in Junior and High School. Boston: Allyn and Bacon.

Leongson, J. A. \& Limjap, A. A. 2005. Assessing The Mathematics Achievement of College Freshmen Using Piaget's Logical Operations. International Journal for Mathematics Teaching and Learning: 4 (13): 86.

Mendiknas. 2010. Pengembangan Pendidikan Budaya dan Karakter Bangsa. Jakarta: Balitbang

Miguel C. R. 2006. A Mathematical Problem-Formulating Strategy. International Journal for Mathematics Teaching and Learning: 12 (7): 79.

Muslimin, I., dkk. 2000. Pembelajaran Berdasarkan Masalah. Surabaya: Unesa-University Press.

NCTM. 2000. Principles and Standards for School Mathematics. (Online)

(http://www.nctm.org/standards/f ocalpoints. aspx?id=284, Diakses tgl. 2 April 2009).

Parwati, N.N. 2011. Pengaruh Strategi Pembelajaran dan Jenis Masalah terhadap Kemampuan Pemecahan Masalah Pada Siswa SD yang Memiliki Sikap Berbeda terhadap Matematika. Disertasi, tidak diterbitkan. Malang: Universitas Negeri Malang.

Parwati, N.N., Sudiarta, I.G.P., \& Puja Astawa, I.W. 2008-2010. Pengembangan Model 
Pembelajaran Matematika

Berpendekatan Tematik untuk Mengembangkan Kompetensi Berpikir Kritis dan Kreatif pada Siswa Sekolah Dasar di Provinsi Bali. Laporan penelitian Hibah Bersaing, tidak diterbitkan. Singaraja: Universtas Pendidikan Ganesha.

Rajib, S. \& Noralene, U. 2008. Kearifan Lokal daam Pengurangan Resiko Bencana. Regional Program Officer UN ISDR Asia dan Pacific.

Rizvi, N. F. 2004. Prospective Teachers' Ability to Pose Word Problems. International Journal for Mathematics Teaching and Learning: 10 (12): 79.

Thiagarajan, at al. 1974. Instructional Development for Training teacher of Exceptional Children. Indiana: University Minnesota.

Undang-Undang Republik Indonesia Nomor 20 Tahun 2003 tentang Sistem Pendidikan Nasional. Bandung: Citra Umbara.

Pannen, Paulina dan Purwanto. 2001. Penulisan Bahan Ajar. Jakarta: Pusat antar Universitas untuk Peningkatan dan Pengembangan Aktivitas Intruktional Ditjen Dikti Diknas.

Gijselaers, W.H.(1996). Connecting Problem-Based Practice with Educational Theory. Dalam Wilkerson, L.(Ed). New Direction for Theaching and Learning. No.68. Josey-Bass Publisher.

Ibrahim, Muhsin dkk. (2000). Pembelajaran Kooperatif. Surabaya: University Press.

Suherman, Erman. (2003). Evaluasi Pembelajaran Matematika. Bandung: JICA UPI

Suherman, Erman. (2008). Belajar dan Pembelajaran Matematika. Hand-Out Perkuliahan Jurusan Pendidikan Matematika FPMIPA UPI : tidak diterbitkan

As'ari, S.C. 2005 Teaching Mathematic Problem Solving with a
Workshop Approach and Literature. Virginia: College of William and Mary Williamsburg. [online] tersedia http://www.wm.edu/.../Ashton.pdf Scoenfeld, Alan H. (1980). Heuristik in the Classroom, dalam Krulik, S. dan Reys, Robert E. (Eds). Problem Solving in School Mathematic. Virginia : NCTM. 